\title{
National Mineral-Resource Assessment: The 1996 Estimate of Undiscovered Gold, Silver, Copper, Lead, and Zinc Remaining in the United States
}

\section{Introduction}

Mining has occurred in the United States from pre-Revolutionary times. How much of our Nation's total mineral wealth has already been discovered? How much is left? For conventional-type deposits that contain gold, silver, copper, lead, or zinc, about as much is left to be discovered in the conterminous 48 States as has already been discovered.

\section{Why a Mineral-Resource Assessment Is Needed}

As the Nation's economy matures, progressively greater attention is paid to land use and environmental quality, as to provide for the needs of future generations. National mineral-resource assessments provide a framework for addressing these issues by monitoring the Nation's mineral wealth and by contributing to the debate over resource extraction versus environmental security. For responsible stewardship of our Nation's lands, we need to know in which areas future mineral resources may be located, how much metal such resources might contain, and what environmental impacts might result from extraction of such resources.

The U.S. Geological Survey (USGS) conducted a scientific study to estimate, for the first time, the amount of undiscovered gold, silver, coper, lead, and zinc that could be present in yet-tobe-discovered mineral deposits 1 kilometer or less below the surface of the ground of the conterminous United States. This estimate is based on the best information and theory available to the well as sustainability of mineral supplies

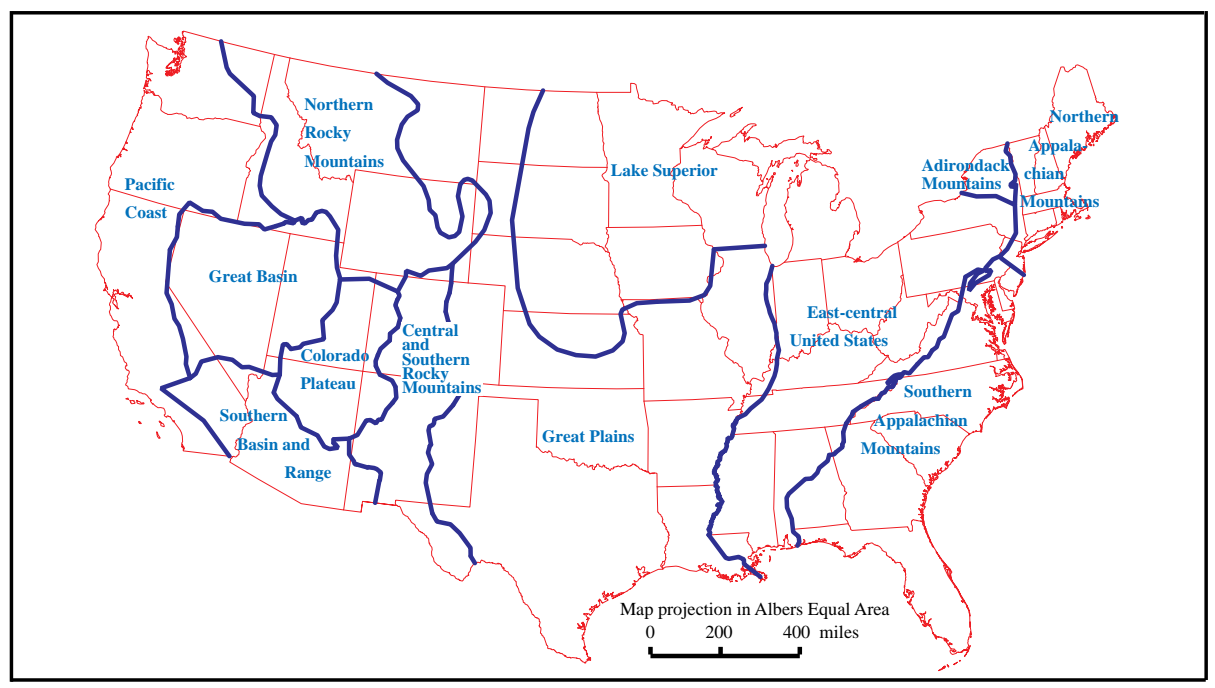

Figure 1. Map of the conterminous United States showing the 12 National mineral-resource assessment regions.
USGS and is the most thorough, welldocumented assessment of undiscovered deposits of gold, silver, copper, lead, and zinc ever assesmbled at this scale. Table 1 summarizes data on U.S. and world resources of gold, silver, copper, lead, and zinc. In Table 1, the estimated undiscovered U.S. resources can be described as the estimated amount of metal expected or most likely to occur in the undiscovered deposits. Statisticians define the values as "the mean of a probability distribution." To estimate undiscovered mineral resources, earth scientists actually begin by analyzing their data and then estimating the number of undiscovered mineral deposits of a specific geologic type that they believe occur in an area. They make this estimate at several levels of certainty. For example, they may estimate from the geologic data that there is a 90 -percent
Table 1. U.S. and world resources of gold, silver, copper, lead, and zinc.

\begin{tabular}{|c|c|c|c|c|c|}
\hline & $\begin{array}{l}\text { Gold } \\
\text { (tons) }\end{array}$ & $\begin{array}{l}\text { Silver } \\
\text { (tons) }\end{array}$ & $\begin{array}{c}\text { Copper } \\
\text { (kilotons) }\end{array}$ & $\begin{array}{c}\text { Lead } \\
\text { (kilotons) }\end{array}$ & $\begin{array}{c}\text { Zinc } \\
\text { (kilotons) }\end{array}$ \\
\hline \multicolumn{6}{|l|}{ Estimated undiscovered } \\
\hline $\begin{array}{l}\text { U.S. resources } \\
\text { Discovered U.S. resources } 1\end{array}$ & $\begin{array}{l}14,000 \\
22,000\end{array}$ & $\begin{array}{l}430,000 \\
400,000\end{array}$ & $\begin{array}{l}280,000 \\
320,000\end{array}$ & $\begin{array}{l}55,000 \\
75,000\end{array}$ & $\begin{array}{l}150,000 \\
140,000\end{array}$ \\
\hline \multirow{2}{*}{$\begin{array}{l}\text { Total U.S. resources } \\
\text { Minable world resources, } \\
\text { excluding the United States } 2\end{array}$} & 36,000 & 830,000 & 600,000 & 130,000 & 290,000 \\
\hline & 61,000 & 390,000 & 570,000 & 110,000 & 310,000 \\
\hline \multicolumn{6}{|c|}{$\begin{array}{l}{ }^{1} \text { Estimates of discovered resources based on Singer, D.A., 1995, World class base and precious metal } \\
\text { deposits-A quantitative analysis: Economic Geology, v. } 90 \text {, p. } 88-104 . \\
{ }^{2} \text { Same as the estimates of the Total, Reserve base, World total (excluding the United States) based on U.S. } \\
\text { Geological Survey, 1996, Mineral Commodity Summaries 1996, } 195 \text { p. }\end{array}$} \\
\hline
\end{tabular}

chance that the area has at least 1 or more undiscovered deposits of a specific type; a 50-percent chance of 3 or more deposits; and a 10-percent chance of 5 or more. They also know the amounts of metal contained in both large and small deposits of this type previously discovered in the area, nearby, and often around the world. With statistical methods and with the aid of a computer, scientists can combine their estimates with the information on the metal contents of discovered deposits to predict the probable amounts of metal expected to occur in undiscovered deposits in the study area.

\section{How the Assessment Was Done}

The assessment was based on mineraldeposit models. These models are sets of data that describe a group of deposits that have similar geologic characteristics, form in similar geologic settings, and have distinctive sizes and distinctive amounts of metal. Earth scientists begin an assessment by outlining large regions having geologic characteristics and settings broadly similar to those of one or more mineral-deposit models. Subsequently, scientists examine the geology of the region in detail in order to outline much smaller tracts of land having geologic features that more closely match those of the models. These tracts are considered to be permissive for the occurrence of a specific type of mineral deposit. A total of 46 mineral-deposit models were used to delineate 12 regions (fig. 1, table 2) and 281 permissive tracts (fig. 2) in the conterminous United 


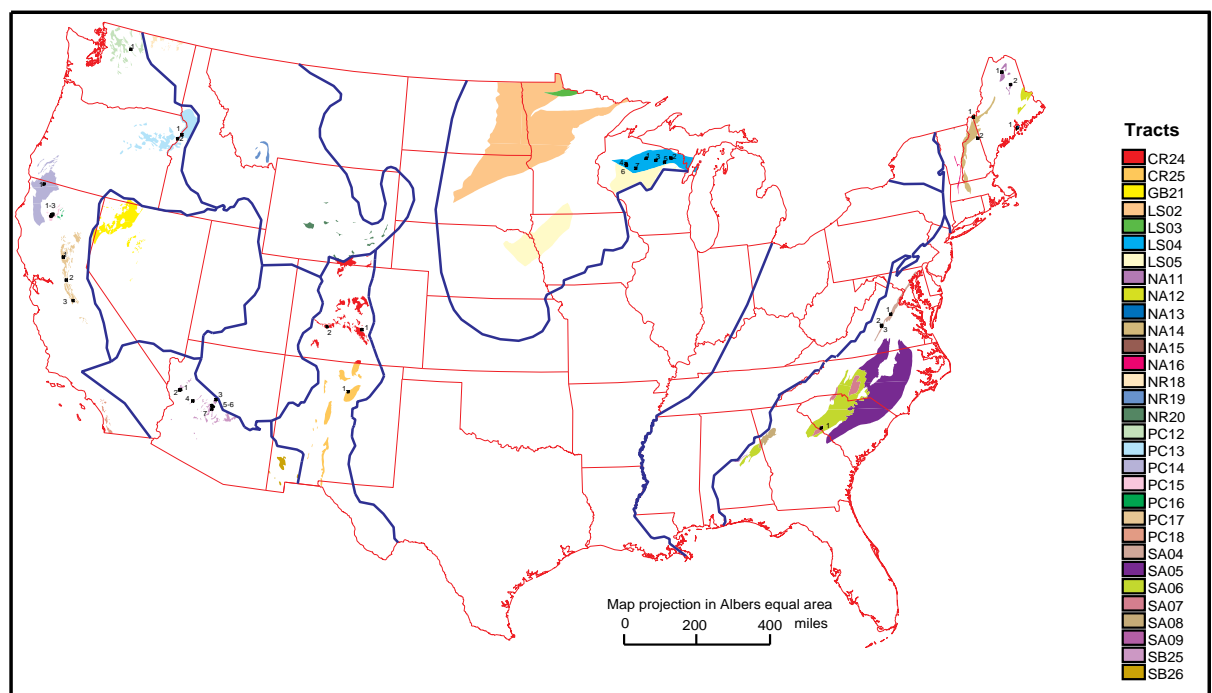

Figure 2. Example permissive tract map - Kuroko-type massive sulfide deposit.

Table 2. Results of the National assessment by region.

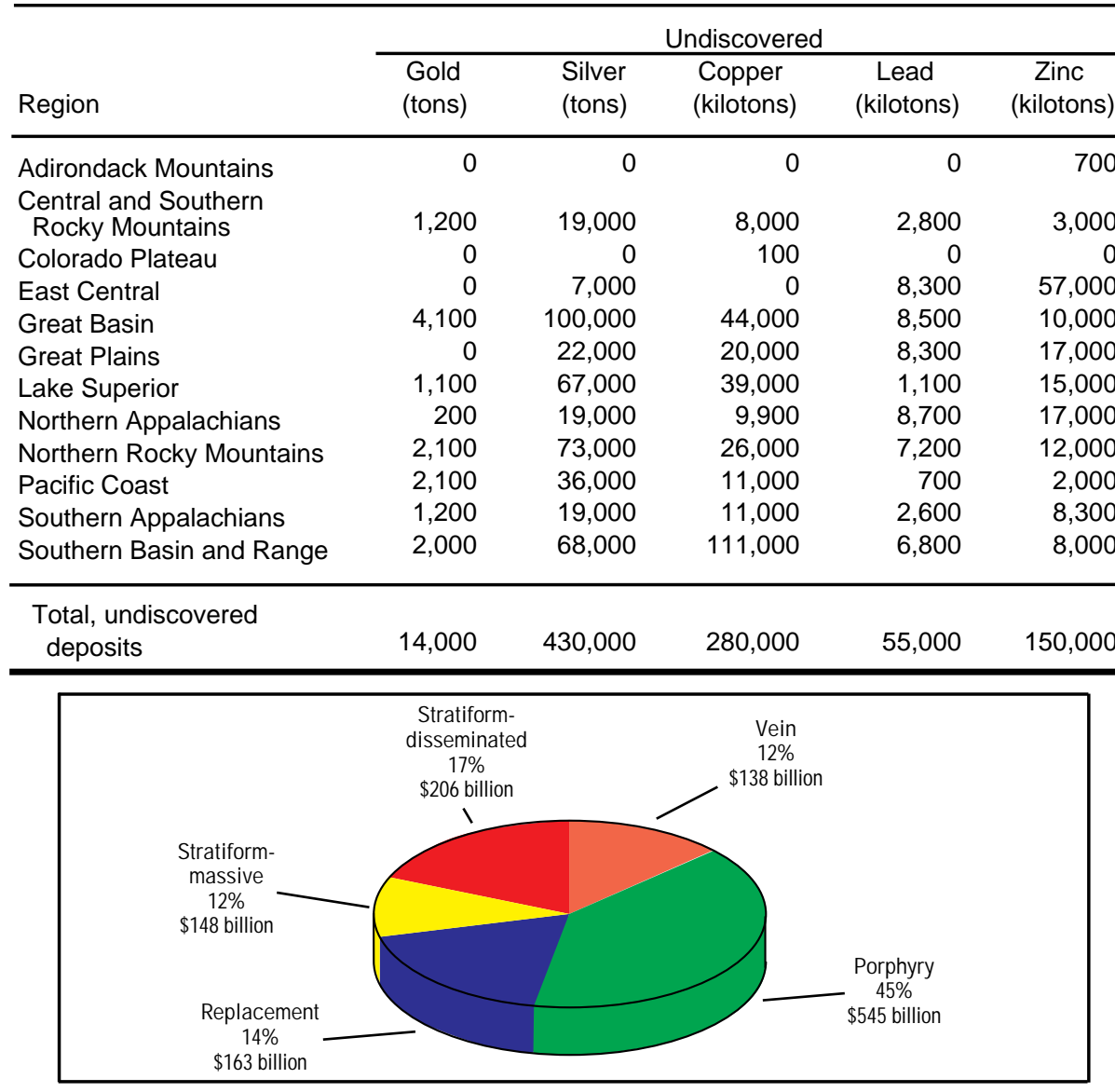

Figure 3. Gross value, in U.S. dollars, of the five general deposit types.

Table 3. Results of the National assessment by mineral deposit types.

\begin{tabular}{lrrrrr}
\hline & \multicolumn{5}{c}{ Undiscovered } \\
\cline { 2 - 6 } General mineral deposit type & \multicolumn{1}{c}{$\begin{array}{l}\text { Gold } \\
\text { (tons) }\end{array}$} & \multicolumn{1}{c}{$\begin{array}{c}\text { Silver } \\
\text { (tons) }\end{array}$} & $\begin{array}{c}\text { Copper } \\
\text { (kilotons) }\end{array}$ & $\begin{array}{c}\text { Lead } \\
\text { (kilotons) }\end{array}$ & $\begin{array}{c}\text { Zinc } \\
\text { (kilotons) }\end{array}$ \\
\hline Vein & 7,800 & 120,000 & 9,000 & 0 & 0 \\
Porphyry & 2,800 & 42,000 & 190,000 & 0 & 0 \\
Replacement & 400 & 75,000 & 4,000 & 36,000 & 97,000 \\
Stratiform-massive & 900 & 53,000 & 19,000 & 19,000 & 53,000 \\
Stratiform-disseminated & 2,100 & 140,000 & 58,000 & 0 & 0 \\
\hline$\quad$ Total, undiscovered & & & & & \\
$\quad$ resources & 14,000 & 430,000 & 280,000 & 55,000 & 150,000 \\
\hline
\end{tabular}

States. These models fall into five general types of mineral deposits called vein, porphyry, replacement, stratiformmassive, and stratiform-disseminated deposits. Some of the deposit types contain all five metals (gold, silver, copper, lead, and zinc), some contain only one or two, and some of these metals are present in only small amounts (table 3).

At today?s prices, the gross value of gold, silver, copper, lead, and zinc in undiscovered deposits is estimated to be $\$ 1.2$ trillion. Included in this gross value are the value of the metals, the cost of salaries paid for labor to find the metals and to build and operate the facilities to extract and refine them, and the returns (profits) to investors in metals exploration and development. The gross value of the five metals in undiscovered deposits can be compared with the gross value of the discovered (past production plus remaining reserves) gold, silver, copper, lead, and zinc, which is calculated to be $\$ 1.4$ trillion. Thus, for conventional-type deposits in the conterminous 48 States, about as much is left to be discovered as has already been discovered. The gross value of the five metals in undiscovered deposits by general mineral-deposit type is shown in figure 3. This assessment marks the beginning of an ongoing assessment by the USGS of all mineral resources in the United States. Detailed results of the National assessment are available in USGS Open-File Report 961̈96, Data Base for a National Mineral-Resource Assessment of Undiscovered Deposits of Gold, Silver, Copper, Lead, and Zinc in the Conterminous United States. This report is available on CD-ROM from the USGS Information Services, Box 25286, Denver Federal Center, Denver CO 80225-0046, Tel: 303-202-4700; Fax 303-202-4188. The data base consists of a series of computer files in Microsoft Excel, Microsoft Word, and Adobe Illustrator formats. These can be used to generate tables, text files, maps, and graphs, along with an executable Adobe Acrobat file that can be used with the following operating systems: Macintosh $\mathrm{OS}^{\mathrm{TM}}$, MS-DOS ${ }^{\mathrm{TM}}$, Windows $3.1^{\mathrm{TM}}$ Windows $95^{\mathrm{TM}}$, Windows $98^{\mathrm{TM}}$, Windows $\mathrm{NT}^{\mathrm{TM}}$, and UNIX. ${ }^{1}$

\footnotetext{
descriptive purposes only and does not imply endorsement by the U.S. Government.

Joseph A. Briskey, Jr.

U.S. Geological Survey

National Center, MS 954

Reston, Va 20192

Telephone: (703) 648-6112

E-Mail: jbriskey@usgs.gov or

Paul G. Schruben

U.S. Geological Survey

National Center, MS 954

Reston, Va 20192

Telephone: (703) 648-6142

E-Mail: pschrube@usgs.gov
}

${ }^{1}$ Any use of trade, firm, or product names is for

\section{For more information, please contact:}

